\title{
"Seeing off a Recruit": The Ritual and Its Songs in the Udmurt Traditional Culture
}

\section{Valeriia Fedorova}

e-mail: loptem.gon@ya.ru

\begin{abstract}
The rite of Seeing Off a Recruit is one of the most relevant Udmurt family rite traditions that is still performed. Conscription is of particular importance in the life of the Udmurt family and recruit. This article aims to study the songs performed in the rite, and more precisely, their functions of performance at different stages such as the symbolic patterns and items that build a connection between the rite songs and the rite itself. The ethnographic data collected is based on the tradition of the village of Chutozhmon, Malaya Purga District in the Udmurt Republic of the Russian Federation.

Through analysis of the data, I construct a detailed description and scenario for the rite of Seeing Off a Recruit. The model for the rite is similar in all Udmurt traditions, although the song component is rather different depending on the village. The original songs and tunes used in the village of Chutozhmon are well preserved and create a complete picture of the rite, thus it has been possible to thoroughly research it.
\end{abstract}

Keywords: folk song, rite, ritual, Russia, seeing off, symbols, Udmurt tradition 


\section{Introduction}

The rite of Seeing off a Recruit is one of the most relevant functioning family rites in the Udmurt tradition to this day and retains local differences even in this age of globalisation. It preserves its ritual features, follows its original scenario and has no analogue; in many local traditions, the ritual tunes and songs that accompany the significant actions of the ritual are still known.

This tradition is an extensive topic for research as the rite can be studied from ethnographic, religious, historical, linguistic, anthropological, poetic, ethnomusicological, and other perspectives, although there has not been much research yet.

Seeing off a Recruit as a rite began only in the $18^{\text {th }}$ century, after Peter the Great issued a decree introducing compulsory military service on February $20^{\text {th }} 1705$. Thus, it is a relatively 'young' rite in comparison with others. The need for the rite was natural: initially recruits were conscripted into the tsarist army for life, later reduced to 25 years, although in both cases they might never return home. Today, the duration of service is shorter at five years during the Soviet, then afterwards three years, and now only one or two years for every young man. However, it is still necessary to conduct the rite because the Udmurt believe that the young men are going to an unknown, alien world, and the ritual will help them serve well and return home healthy. This is also a kind of initiation rite for the young men with becoming a soldier treated as a step towards adulthood. Once the rite is completed the recruit is no longer seen as a boy - serving in the army is serious and hard work, and after returning home the soldier becomes a respected adult.

The rite of Seeing off a Recruit in the Udmurt language varies from district to district, from village to village. It is called saldate kel'an 'seeing off to soldiery', saldatpi kel'an 'seeing off of a soldier', 
armiye kel'an 'seeing off to the army'. The ritual songs also have different names, in parallel: saldat kel'an gur 'the tune of seeing off the soldier', saldate kel'an gur 'the tune of seeing off to the soldiery', saldatpi kel'an gur 'the tune of seeing off the soldier boy', armiye kel'an gur 'the tune of seeing off to the army', saldat gur 'the tune of the soldier', saldatpi gur 'the tune of the soldier boy', l'ekrut gur or l'ekurt gur 'the tune of the recruit'. The word gur means 'tune', but here it can also be translated as 'song' because, for example, the 'archaic' songs are sung to the same tune but can have different names relating to the situations they are for. Only a certain song can be used at a certain stage of the rite. The informants (tradition-bearers) distinguish the purpose of the songs by their tunes because some lyrics can be universal for all rites.

This article is based on data collected in the Udmurt village of Chutozhmon in Malaya Purga District on expeditions to that village and the village of Baykuzino in the same district between 2015 and 2018. Chutozhmon is a small village the population of which was never more than 300 people. It was founded in the second half of the $18^{\text {th }}$ century, approximately in 1750-1780. The first settlers were from Malaya Purga, which is now the district centre (Atamanov 2005: 169-170). Today, fewer than 50 people live in Chutozhmon and it is possible to say that the folk tradition of the village has already disappeared because the inhabitants are all elderly. They have no opportunity to perform the rite, but they can talk about the past and sing the traditional songs. Fourteen different songs were recorded in the village (not counting duplicate recordings).

Every Udmurt rite has a special tune and set of songs, although some songs are common to all rites. Moreover, tunes for the same rite are different in almost every village, while the lyrics can coincide. So, in one village, people have different kinds of tune wedding tunes (always two in the Udmurt tradition), tunes for 
meeting guests, tunes for particular calendar holidays, or tunes for seeing off a recruit - even though the lyrics can be the same. Despite the differences in the rite of Seeing off a Recruit in different Udmurt traditions, the main content remains the same: the recruit bids farewell to family, friends, beloved, fellow villagers, house, and the village itself. Elena Boykova and Tatiana Vladykina (1992: 15) concludmutied that according to ethnographic data, the earliest form of the rite consisted of two main stages: moving "from house to house" and departure.

Since soldiers might not return home, some rituals are supposed to help them return safely as well as to influence positively their future. Pinning a red ribbon to a ceiling beam or to the gate was a special way of leaving the house, a ritual farewell to everything that surrounded the recruit (including inanimate objects like the house, other buildings, natural objects, etc.). The recruit must leave something as a reminder of himself as a substitute during his period of absence. Usually this is the red ribbon, or it could be a piece of red fabric, that thus becomes an icon. The beam is believed to possess magical properties, and to protect the soldier from trouble because of the connection through the red ribbon. His family and girls from the village also make symbolic gifts of towels and handkerchiefs. There are also different symbolic items in the rite, for example ribbons (especially red), coins, a knife, and white towels.

The rituals in the rite were always aimed at the recruit's safe return. The Udmurt attempted to follow his fate with some omens. For example, Tatiana Vladykina writes that, in some Udmurt traditions, the recruit was associated with a young spruce. To know whether he was to return home or not, the young boy chopped off a shoot at the top of a tree, or skinned part of the trunk at the top so that the tree would have the appearance or silhouette of a person. If the tree did not dry out, he would return (2004: 56-57). 


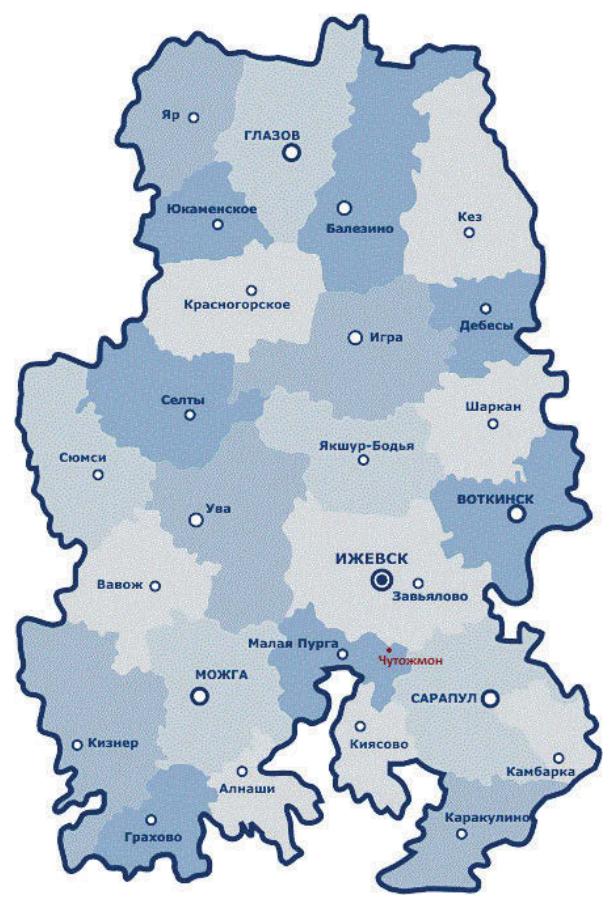

Map 1. Map of The Udmurt Republic with the village of Chutozhmon marked in red. Source: http://www.udmgossovet.ru/interaction/local/regions/.

\section{Previous research}

Researchers' interest in ritual songs appeared at the end of the $19^{\text {th }}$ century. They used the philological approach in the systematisation of songs until the 1990s and turned to musicology 
only at the end of the $20^{\text {th }}$ century. Modern ethnomusicologists classify Udmurt folk songs according to their functional confinement and distinguish ritual songs (timed to the folk calendar and family or tribal holidays) and non-ritual songs (ditties, lyric songs, etc.).

Udmurt rite songs are extensively represented by now, and thus there is a good basis for research. The Udmurt Research Institute ${ }^{1}$ published a series of ritual songs called Udmurt Folklore. Each book in the series is dedicated to specific local traditions, for instance, southern or northern Udmurtia, as well as regions outside the Republic, where Udmurts live and preserve Udmurt traditions (for example Bashkortostan, Tatarstan, Perm Krai, Kirov Oblast, etc.). In these series, the researchers present accurate musical decoding, detailed information about informants, descriptions of the region or locality, and the specifics of the local traditions.

The first mentions of Seeing off a Recruit can be found in books of older ethnographers and writers such as Nikolai Pervukhin (1888), Petr Bogaevskiy (1888), and Grigoriy Vereshchagin (1889), where they describe the rite held in Sarapul and Glazov counties (uezd) in Vyatka Governorate.

Active study of the rite of Seeing off a Recruit began at the end of the $20^{\text {th }}$ century, with research by Russian and Udmurt scholars such as Elena Boykova, Elena Vershinina, Tatiana Vladykina (Perevozchikova), Petr Pozdeev, Irina Pchelovodova, Lyudmila Khristolyubova, Al'bert Shakhovskoy, who produced mainly descriptive work that acts as a good database of information about the rite.

Petr Pozdeev (1967: 32-33) concluded that related songs are similar to those that were sung when seeing off a bride during the wedding. These songs were seen as appropriate for this rite too because the roles of both recruit and bride are similar in that way that they are going to an 'alien world' and are not expected back in their home or land. Vershinina and Vladykina (2014) agree with this but more research on this topic is needed. 
The structure of the texts of the songs is composed of stable motifs: receiving the call-up, certifying fitness for service, parting with relatives and the native home, opposition between peaceful everyday lives and the soldiers' lot. In content, all the songs are commentaries on ritual acts (Vladykina et al. 2018: 144). In 1888, Bogaevskiy emphasised in his essay that all songs are functionally important in the rite structure because continuity means that a particular song is performed at a certain time and place.

\section{Methods}

This research intended to reconstruct, on the basis of the collected information, the scenario of the rite. The songs were collected in the villages of Chutozhmon and Baykuzino, and in the capital of Udmurtia, Izhevsk, where tradition-bearers (so-called informants) from Chutozhmon lived. I relied on data from the Internet as well as lyrics in songbooks and available musical decodings of the rite songs from across the spectrum of Udmurt culture. The data (the songs and narration of the informants) regarding the rite were recorded between 2014 and 2018. The scenario of the rite was reconstructed relying mostly on materials from the village of Chutozhmon.

\section{Detailed Description of the Rite of Seeing off a Recruit}

By using rare sources from the $19^{\text {th }}$ century, it is possible to give a full description of the Udmurt rite of Seeing off a Recruit, and from this to conclude that it coincides with the same rite held in the recent past in the village of Chutozhmon, Malaya Purga district of the Udmurt Republic. 
The rite began on the day the recruit received his call-up papers and became aware of the date of his admission into the army. On the same day, the whole village received the news. The closest relatives of the recruit and the families of his friends were honour-bound to invite him to their house and agreed among themselves on the order of invitation. Because there might also be other recruits in the village, all of them were supposed to move together from house to house for refreshments and to perform certain rituals in every house. These visits took place before the recruits' departure, usually on a single day. Each recruit was dressed in casual clothes, with a jacket that was part of the holiday outfit, and a hat. On the right side of the jacket, on the chest there was a big pin onto which girls tied long colored ribbons while the recruit went around the village (if there was not enough space, they hooked on another pin). A pin was also attached to the cap at the back, to which girls tied more long colored ribbons. The recruit and the company of his friends rode through the village streets on the best cart with horse(s). The arch of the cart was decorated with bells, ribbons, and towels. Later, when there were no longer horses in the village, the recruit and his friends went from house to house on foot singing songs in all the houses. There was usually a single tune that was sung with different lyrics starting first at the gates of the houses. Knocking on the gate or without knocking (if they were invited by the hosts), the recruit and his company sang soldate kel'an gur, 'seeing off to soldiery'. 


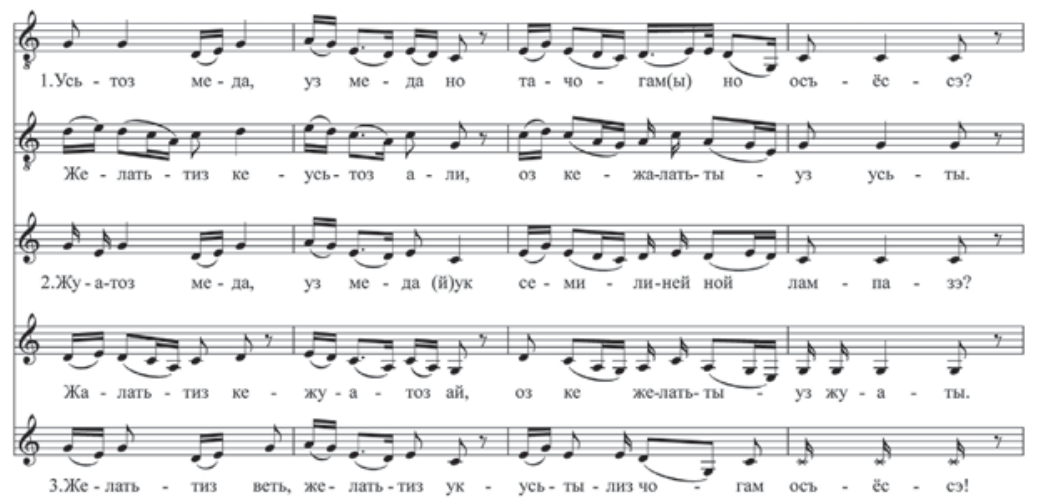

Figure 1. The text of Seeing off a Recruit. Saldatez yumshaton ('The Soldier Festivities') 2 .

Saldatez yumshaton

Us'toz(y) meda, $u z(y)$ meda (y) Will they open their locked uk ta tshogam(y) no ös"yosse? doors or not?

Zhelat'tiz ke - us'toz al'i, öz ke If they wish - they will open, zhelat'ty - uz us'ty.

Dzhuatoz(y) meda, uz(y) meda

(y)uk s'emil'in'eynoy lampaze?

Zhelat'tiz ke - dzhuatoz ay, öz ke zhelat'ty - uz dzhuaty.

Dzhuatiz al'i, dzhuatiz al'i s'emil'en'eynoy lampaze.

Zhelat'tiz vet', zhelat'tiz ukus'tyliz tshogam ös"yosse.
The Soldier Festivities if not - they will not open.

Will they light the seven-line (kerosene) lamp or not?

If they wish - they will light, if not - they will not light. They lit, they lit the seven-line (kerosene) lamp.

They wished, they wished they opened the locked doors.

When the doors were open, guests came in and sang the same tune but with other lyrics explaining the purpose of their visit: 


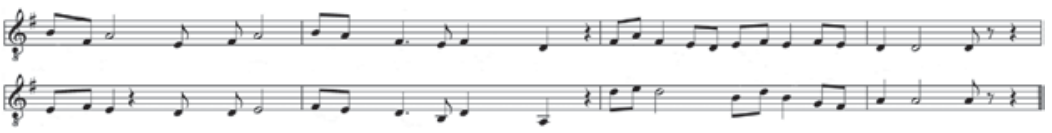

Figure 2. The tune of Seeing off a Recruit. Saldatez yumshaton ('The Soldier Festivities'). ${ }^{3}$

Saldatez yumshaton

Dzh'ech ivor no kylis'kiz no, mi The good news was heard, and pyrono karis'kim.

Dzh'ech ivor no kylis'kiz no, mi pyrono karis'kim.

Mi pyrem no, oy, pönna (y)uk vozh"yostes no en vaye.

Mi pyrem no, oy, pönna (y)uk vozh"yostes no en vaye.
The Soldier Festivities we decided to visit you.

The good news was heard, and we decided to visit you.

Do not become angry that we came in.

Do not become angry that we came in.

Guests were invited to sit at the table, eat and drink some wine. For the ritual of hammering a ribbon, the hosts gave the recruit a red ribbon, a coin, a knife, and put forth a chair. The recruit got up on the chair to hammer the ribbon onto the beam.

The beam is an important part of the house not only because it supports the ceiling of a wooden house in the middle, but also because it has semantic meaning as the division of the house into two parts, private and external. People could go to the private zone only with the permission of the hosts. The recruit and everybody else stood against the front door in the private zone of the house.

The leader singer started to sing a recruit tune with other lyrics for the ritual of hammering a ribbon (for more details, see below):

Gord armiye bas'tizy no gord chuk shukkyny kosizy.
I was taken to the Red Army and they forced me to hammer a red ribbon. 
Ta shukkem no, oy, chuk"yosme Keep these hammered ribbons achim bertoz' voz'ele. until my return.

Mone addzh'emdy potyliz ke, If you want to see me, look at ta chuk shoram uchkele. my ribbon.

Mone addzh'emdy öz ke poty, If you do not want to see me, yshkaltysa kushtele. pull it off and throw it away.

Tapala ke berytskono, ta purt If I am to come back here, let metshak med merchchoz. this knife stick into the floor. Sopala ke, oy, byrono, ta purt If I am to die there, let this urdesly n'i met us'oz. knife just fall sideways. Bertoz al'i, ta purt metshak merchchas'kiz. He will come back, he will come back, this knife has stuck into the floor.

Tapala bertemen ivor kylis'kiz If you want to hear news ke, mul'y bas'tysa das'ale. about my return, buy sunflower seeds.

Sopala byremen ivor kylis'kiz If you want to hear the about my ke, s'us'tyl dzhuatsa vös'as'ke. death, light a candle and pray.

\section{Text of Seeing off a Recruit. Chuk shukkon gur (Song for Hammering a Ribbon) ${ }^{4}$}

During the song, the recruit stuck the red ribbon into the beam with the edge of a knife, then hammered a coin onto the red ribbon with the handle of a knife (in other Udmurt traditions a hammer or axe was used instead of a knife). After that, guessing his future, the recruit threw the knife onto the floor while singing: "Tapala ke berytskono, ta purt metshak med merchchoz..." ('If I am to come here back, let this knife stick into the floor...'). Everyone looked at how the knife fell. If it stood upright, it meant that the young man 
would return home safely after service, if the knife fell sideways, it was considered a bad omen, according to the lyrics.

After this ritual of hammering a ribbon, the recruit descended from the chair and thanked the hosts. Girls in every house gave him different gifts, such as embroidered handkerchiefs, here they tied colored ribbons to the pins on his jacket and hat, and the hosts gave him white towels (previously, only the godmother gave a towel, while the parents gave neither scarves nor towels).

Moving to the next house, the young people thanked the hosts with the same tune as Seeing Off a Recruit set to other lyrics ${ }^{5}$ :

Saldatez yumshaton

Taule no, taule no, s'udem(y)ly no s'ektam $(y) l y$.

Taule no, taule no, s'udem(y)ly no s'ektam $(y) l y$.

Mil'am(y) s'iyem-yuem intyyamy

Inmar kuin'men med s'otoz.

Mil'am(y) s'iyem-yuem intyyamy

Inmar kuin'men med s'otoz.
The Soldier Festivities

Thank you, thank you for food and drink.

Thank you, thank you for food and drink.

God must give you three times more for your hospitality.

God must give you three times more for your hospitality.

Everything was repeated in the next houses. In the meantime, in the streets or sitting on the bench in front of houses, they also sang. They could sing Russian Soviet songs, army songs or songs about parting. In Chitozhmon, the informants remember that they were singing songs like "Kak rodnaya men'a mat'provozhala”, "Oy, krasivy nad Volgoy zakaty", and "Dobryy vecher, devushki”. These songs have an author and composer, so people probably heard them on the radio.

Here some examples of these Russian songs ${ }^{6}$ : 


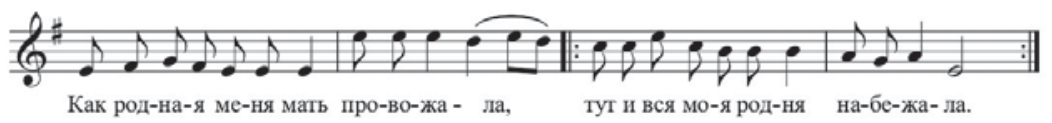

Figure 3. Provody ('Seeing off'). Original lyrics by Dem'yan Bednyy.

Full text from: http://a-pesni.org/grvojna/kr/provody.php.

Provody $^{7}$

Kak rodnaya men'a mat'

provozhala,

Tut i vs'a moya rodn'a nabezhala.

Tut i vs'a moya rodn'a nabezhala.

Oy, kuda zh ty, paren'ok, oy, kuda ty?

Ne khodil by ty Van'ok vo soldaty,

Ne khodil by ty Van'ok vo soldaty.

V Krasnoy Armii shtyki, chay, nayduts'a,

Bez men'a bol'sheviki

oboyduts'a.

Bez men'a bol'sheviki

oboyduts'a.
Seeing off

As my mother was seeing me off,

And all my relatives came running.

And all my relatives came running.

Oh, where are you going, boy, oh, where are you going?

You wouldn't go to soldiery, Vanyok.

You wouldn't go to soldiery, Vanyok.

There are enough bayonets in the Red Army, The Bolsheviks will manage without me.

The Bolsheviks will manage without me. 
Ponevole ty id'osh al's okhotoy, Van'a, Van'a, propad'osh n’iza chto ty.

Van'a, Van'a, propadyosh n’i za chto ty.

Mat'stradaya po tebe

posedela,

Evon v pol'e i v izbe skol'ko d'ela.

Evon v pol'e i v izbe skol'ko d'ela.

A d'ela t'eper'poshl'i l'ubomilo,

Skol'ko srazu k nam z'eml'i prival'ilo.

Skol'ko srazu k nam z'eml'i prival'ilo.

Ut'esn'en'iy prezhn'ikh n'et iv pomin'e.

Luchshe b ty zhen'ils'a, svet, na Arin'e.

Luchshe b ty zhen'ils'a, svet, na Arin'e.

$S$ molodoy by zhil zhenoy, n'e l'en'ils'a.

Tut ya mat'eri rodnoy poklon'ils'a,
You go involuntarily or with pleasure,

Vanya, Vanya, you'll die for nothing.

Vanya, Vanya, you'll die for nothing.

Mother turned gray suffering for you,

Look how much work in the field and the hut.

Look how much work in the field and the hut.

And now the things went nicely,

How much land immediately fell upon us.

How much land immediately fell upon us.

There is no trace of former oppression,

It would be better if you married Anna, dear.

It would be better if you married Anna, dear.

You would live with a young wife, you would not be lazy, Then I bowed to my mother. 
Tut ya mat'eri rodnoy

Then I bowed to my mother poklon'ils'a,

Poklon'ils'a vsey rodn'e u poroga, N'e skul'it'e vy po mn'e, rad'i Boga.

N'e skul'it'e vy po mn'e, rad'i

Boga.

Bud' takiye vs'e kak vy, rotoz'ei,

Chto b ostalos' ot Moskvy, ot Rassei?

Chto b ostalos' ot Moskvy, ot Rassei?

Vs'o poshlo b na staryy lad, na n'edolgo,

Vz'al'i b vs'o u nas nazad, z'eml'u, vol'u.

Vz'al'i b vs'o u nas nazad, z'eml'u, vol'u.

S'el by barin na z'eml'e zlym Mal'utoy, My b zavyl'i v kabal'e samoy l'utoy.
I bowed to all relatives at the doorstep,

Don't whine at me, for God's sake.

Don't whine at me, for God's sake.

If all were like you loafers,

What would be left of Moscow, of Russia?

What would be left of Moscow, of Russia?

Everything would go in the old way, in shortage, They would take everything back from us - the field, the will.

They would take everything back from us - the field, the will

A gentleman would sit on land as evil Malyuta, We would howl in the fiercest bondage. 
My b zavyl'i v kabal'e samoy l'utoy.

A idu ya n'e na pl'as, na pirushku,

Pokidayuchi na vas mat' starushku.

Pokidayuchi na vas mat' starushku.

S Krasnoy Armiyey poydu ya pokhodom,

Smertnyy boy ya povedu $s$ barskim sbrodom.

Smertnyy boy ya povedu $s$ barskim sbrodom.

Chto s popom, chto $s$ kulakom - vs'a bes'eda:

V br'ukho tolstoye shtykom miroyeda!

$V$ br'ukho tolstoye shtykom miroyeda!

N'e sdayoshs'a! Pomiray, shut s toboyu!

Bud'et nam mil'eye ray, vz'atyy s boyu.

Bud'et nam mil'eye ray, vz'atyy s boyu.
We would howl in the fiercest bondage.

And I'm not going to a dance, to a feast, Leaving you my old mother.

Leaving you my old mother.

I'll go on a campaign with the Red Army, I will lead a mortal battle with a lordly rabble. I will lead a mortal battle with a lordly rabble.

What's with the priest, what's with the kulak - the whole conversation:

A bayonet to the fat belly of the world-eater!

A bayonet to the fat belly of the world-eater!

Don't give up! Die, the jester with you!

Paradise taken from battle will be sweeter to us. Paradise taken from battle will be sweeter to us. 
N'e krovavyy, p'yanyy ray miroyedskiy

Rus' rodnaya, vol'nyy kray, kray Sovetskiy!

Rus' rodnaya, vol'nyy kray, kray Sovetskiy!
Not a bloody, drunken paradise of the world-eaters, But Russia native, free land, Soviet land!

But Russia native, free land, Soviet land!

Another example:

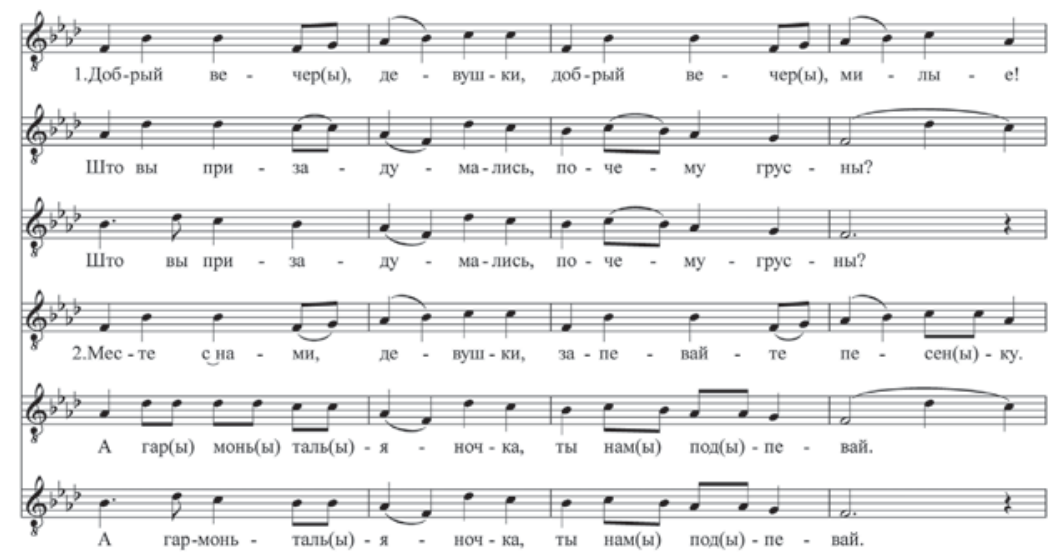

Figure 4. Dobryy vecher, devushki ('Good evening, girls'). Original lyrics and music by Pavel Dmitriev-Kabanov. ${ }^{8}$

Dobryy vecher, devushki

Dobryy vecher(y), devushki, dobryy vecher(y), milye. Shto vy prizadumal'is', pochemu grusny?

Shto vy prizadumal'is', pochemu grusny?
Good evening, girls

Good evening, girls, good evening, dears.

What are you thinking about, why are you sad?

What are you thinking about, why are you sad? 
[V]m'est'e s nami, devushki, Girls, sing a song together zapevayt'e pes'en $(y) k u$. with us, A, gar(y)mon'(y)-tal'(y)yanochka, ty $\operatorname{nam}(y) \operatorname{pod}(y)$ pevay.

And Talianka accordion, you A, gar $(y) \operatorname{mon}^{\prime}(y)-\operatorname{tal}^{\prime}(y) y a n o c h k a$, ty $\operatorname{nam}(y) \operatorname{pod}(y)$ pevay. sing along to us.

And Talianka accordion, you sing along to us.

Yed'em(y) s nami, devushki [v] Girls, come with us to the armiyu sovetskuyu, Soviet army

Nashey slav(y)noy Rod'in'eTo serve our glorious mat'eri sluzhit'. Motherland.

Nashey slav(y)noy Rod'in'emat'eri sluzhit'.

To serve our glorious Motherland.

Ne grust'it'e, devushki, n'e grust'it'e, milyye.

Do not be sad, girls, do not be sad, dears.

My op'at' ver(y)n'oms'a $k$ vam, bud'em(y) pomn'it'vas.

We will return to you again,

My op'at' ver(y)n'oms'a $k$ vam, bud'em(y) pomn'it'vas. we will remember you. We will return to you again, we will remember you.

In addition to this there was also some kind of entertainment. People danced, singing ditties to different dance tunes playing on harmony. In the village of Chutozhmon, people danced the quadrille for four people or improvisations in a circle one by one. On this day, the recruit was asked to dance despite his skills. If the recruit was a harmonist or a singer, on this day he will not be left without attention to his talents.

On the evening before departure, the recruit hammered a ribbon into the beam of his family house and all the songs that people had sung in other houses, they sang here again. The house of the recruit was attended by relatives and his friends. Villagers could also come to his house to see him off. Nobody came empty-handed: 
women brought some food, girls gave him embroidered handkerchiefs or pouches, boys could give him paper, pencils for writing letters, tobacco, and sometimes gave money (giving money is a later tradition). Everyone gave something to the recruit with an expression of various good wishes and a request not to forget them. $\mathrm{He}$ thanked everyone and asked them to forgive him if he had said or done anything wrong, and not to remember him badly as they were parting forever (Khristolyubova 1984: 90-111).

Here are some wishes expressed to recruits:

- Inmar dzh'ech s'ures met s'otoz! - God bless your way!

- Kydzh'y ke tatche shuldyr kel'as'kom, odzh'y ik pumitany med kyldoz! - As joyfully we saw you off, so joyfully let us meet you! - Dzh'ech ke vetlid, dzh'ech med bertod! - Safe service and safe return home!

In the house of the recruit, people sang other rite songs to different melodies, which seem to be more modern compared to the recruit tune:

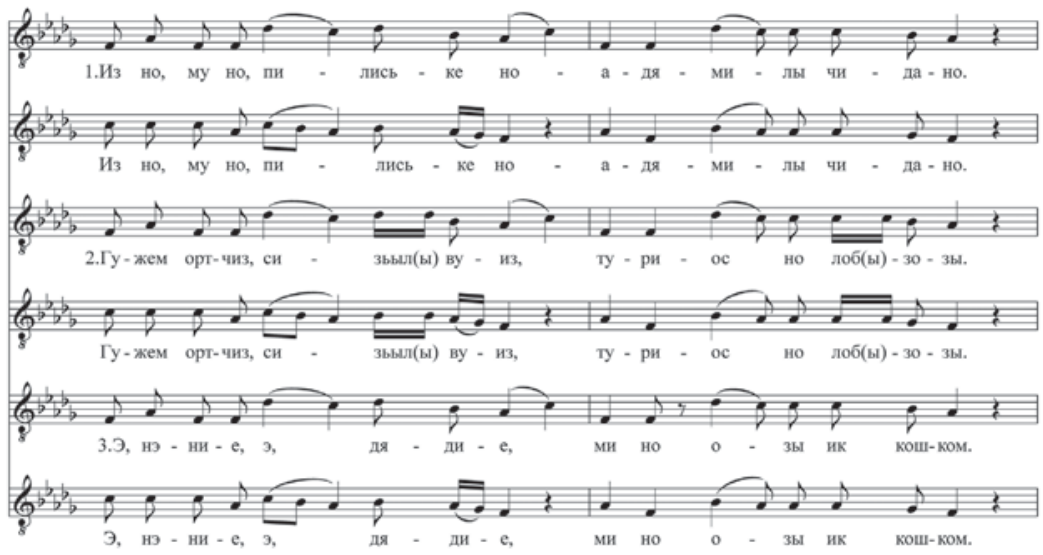

Figure 5. Soldate kel'an gur ('The Song of Seeing off a Recruit'). ${ }^{9}$ 
Soldate kel'an gur

Iz no, mu no pil'is'ke noad'amily chidano.

Iz no, mu no pil'is'ke noad'amily chidano.

S’ödo-s'ödo, oy, pil'em"yos vas'ko, vas'ko Kam kuz'a. S’ödo-s'ödo, oy, pil'em”yos vas'ko, vas'ko Kam kuz'a.

Guzhem ortchiz, siz'yl vuiz, turios no lobdzh'ozy.

Guzhem ortchiz, siz'yl vuiz, turios no lobdzh'ozy.

$E$, nenie, e, d'adiye, mi no oz'y ik koshkom.

$E$, nenie, e, d'adiye, mi no oz'y ik koshkom.

Asme addzh'yton, oy, ponna, fotoosme mon(y) ledzh'o.

Asme addh'zyton, oy, ponna, fotoosme mon(y) ledzh'o.

As'me todyton(y), oy, ponna, I will send you my letters to gozhtet"yosme mon(y) ledzh'o. let you know about me. As'me todyton(y), oy, ponna, I will send you my letters to gozhtet"yosme mon(y) ledzh'o. let you know about me.
The Song of Seeing off

Stone and ground break up the human must endure.

Stone and ground break up the human must endure.

Black black clouds go down above the Kama river. Black black clouds go down above the Kama river.

Summer is over, autumn came, and cranes flew away. Summer is over, autumn came, and cranes flew away.

Oh, my mom, oh, my dad, we will leave in the same way. Oh, my mom, oh, my dad, we will leave in the same way.

I will send my picture to let you see me.

I will send my picture to let you see me. a Recruit 
On the morning of his departure, the recruit got up early, his father harnessed the horses, and his mother prepared his things. Before leaving the house, the recruit visited every building in the family yard. After going around, he took a piece of wood from the beam and took it to the army, so that he always had a piece of his house with him. "In some villages, he drove his ring with a ribbon into the beam as a keepsake. He came out of the house backing away, and his mother threw some fabric under his feet" (Bogaevskiy 1888: 49). According to belief, leaving the house in this way contributed to his speedy and safe return.

"Before leaving the house, he walked around the stove three times and touched the beam, with the words "Atay korka, vuzh korka, med voz'maloz mone" (Father's house, let this old house wait for me). The recruit's mother took his hat and touched the stove with the hat and tossed it over the stove several times to the elder son or someone else. This and the previous actions reveal faith in the protective magic of beam and stove" (Gazieva 2014: 11).

One of the most common traditions of leaving home is when two guys took the recruit in their arms as if "on a chair" (the recruit grabbed friends by their necks). But the recruit could leave the house by himself as in the example of Bogaevskiy (1888). Necessarily he touched the stove and the beam to get some strength and protection from them.

While everybody was going out of the house, they sang: 
Valeriia Fedorova

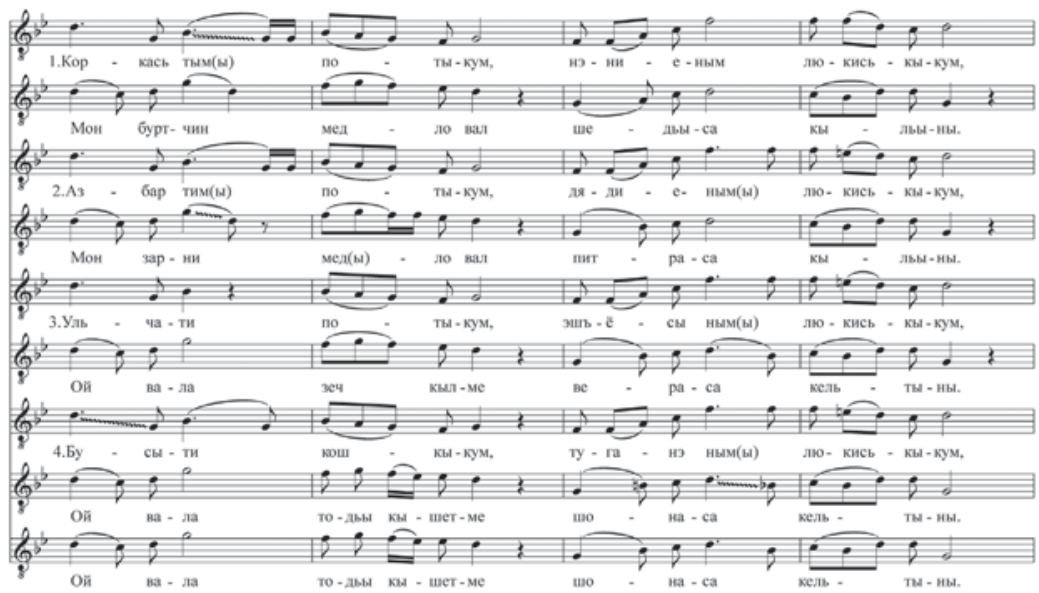

Figure 6. Soldate kel'an gur ('The Song of Seeing off to the Soldiery'). ${ }^{10}$

Soldate kel'an gur

Korkas'tym(y) potykum, neniyenym l'ukis'kykum, Mon burtchin medlo val shegysa kyl'yny.

$\operatorname{Azbartim}(y)$ potykum, d'ad'iyenym(y) l'ukis'kykum, Mon zarn’i med(y)lo val pitrasa kyl'yny.

Ul'chati potykum, esh"yosymy(y) l'ukis'kykum, Öy vala dzh'ech kylme verasa kel'tyny.
The Song of Seeing off to Soldiery

Going out of my house, parting with my mother, I would like to be a silk thread to catch and stay.

Passing through my yard, parting with my father, I would like to be a gold coin to roll off and stay.

Passing along the street, parting with my friends, I did not understand how to say any good word. 
Busyti koshkykum, tuganenym(y) l'ukis'kykum, Öy vala töd'y kyshetme shonasa kel'tyny.
Passing through the field, parting with my beloved, I did not understand how to wave my white handkerchief.

They could also stay a little in the yard and sing another song. All the way to the village gate they walked singing songs:

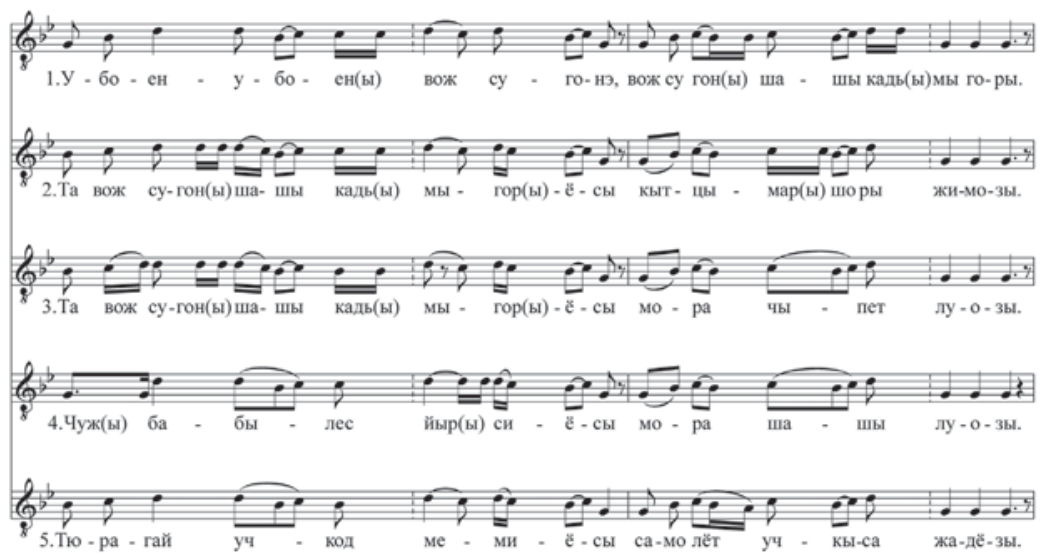

Figure 7. Soldat gur ('Song of the Soldier'). ${ }^{11}$

Soldat gur

Uboyen-uboyen (y) vozh

$\operatorname{sugon}(y)$, shashy kad'(y)

mygor (y).

Ta vozh sugon(y), shashy

kad'(y) mygor(y)yosly, kytstsymar(y) shory dzhimozy?
Song of the Soldier

Bed by bed my green onion, my body is like the leaves of the green onion.

This body is mine, like the leaves of a green onion, where will it go? 
Ta vozh sugon(y), shashy kad'(y) mygor(y)yosy mora tshypet luozy.

Tshuzh babyl'es yyr(y)s'iosy mora shashy luozy.

T'uragay uchkon memiyosy samol'ot uchkysa zhad'ozy.

Gery kuton(y) kikiyosy vin(y)tovka nullysa zhad'ozy. Gery kuton(y) kikiyosy vintovka nullysa zhad'ozy. Borozda l'ogon(y) bybiosy kudzh' s'ures l'ogasa zhad'ozy.

Borozda l'ogon(y) bybiosy kudzh' s'ures l'ogasa zhad'ozy.

En(y) bördy, nenie, en bör $(y) d$, d'ad'ie, ber kyl'em $(y)$ nyl(y)depide dzh'ech vor(y)dy. En(y) bördy, nenie, en bör(y) $d$, d'ad'ie, ber kyl'em(y) nyl(y) de-pide dzh'ech vor(y)dy.
This body of mine, like the leaves of a green onion, will become an obstacle to the sea. My blonde curly hair will become algae.

My parents looking at the nightingale will get tired of expecting a plane.

My hands holding soho will get tired of carrying a rifle. My hands holding soho will get tired of carrying a rifle. My legs stomping the furrow will get tired of treading the long road.

My legs stomping the furrow will get tired of treading the long road.

Don't cry, mum, don't cry, dad, bring up the remaining children well.

Don't cry, mum, don't cry, dad, bring up the remaining children well.

The whole family, relatives, friends, fellow villagers, and his beloved saw off the recruit. The recruit took only one towel and one handkerchief, and left the rest of the ribbons, scarves, and towels to his parents and sister(s) (if he had any). His parents hung these gifts on the wall until he returned.

Horses were already waiting there at the end of the village where the village gate was (two spruces). Later, the horses were waiting 
in front of the recruit's house. The recruit stood in the cart facing the village and waving the handkerchief until he was out of sight.

The last song before leaving was the recruit tune with which the ritual started, ending in different lyrics.

Upon his return, the soldier came to every house where he had hammered red ribbons, and removed them from the beam with his teeth, standing on a chair or raised in the arms of friends as on the eve of his departure.

\section{About the Songs of the Udmurt Rite of Seeing off a Recruit}

There are 14 songs in total which were recorded and which relate to Chutozhmon heritage, and more specifically are intended to be performed as part of the rite of Seeing off a Recruit.

Some reflections about the most archaic layer of the songs in the rite. First of all, it is necessary to define the differences between the different layers of the songs in the village of Chutozhmon. As for the 'archaic' layer, six songs are sung to the same melody, i.e. one archaic tune with different lyrics designed for different contexts. It is very common, in the Udmurt tradition, that every particular rite has its tune - one special melody for one rite but with different lyrics (often used for different purposes). In addition, one of the most indicative features is that every line of the song ends with three unison notes, as in the next figure:

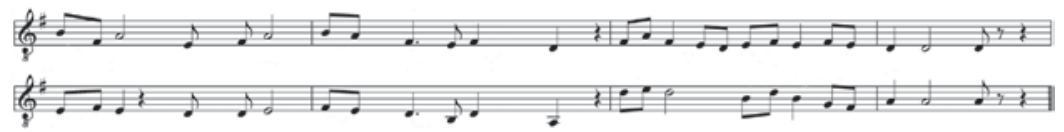

Figure 8. The Tune of Seeing Off a Recruit. 
The 'archaic' songs are those sung to the same melody, to the same tune, and one song which is sung to another tune but which has the abovementioned feature of the ending of the line with three unison notes.

The 'old' layer consists of five songs in Udmurt that are sung to other melodies and melodiously developed on a wide range. These songs could be old lyrical songs suitable for farewell, but it may be assumed that they were composed before the $20^{\text {th }}$ century and had authors. Or they could be the songs performed at wedding as 'seeing off the bride' songs.

The third, 'modern', layer is the three songs that are in Russian from the Soviet period “Kak rodnaya men'a mat' provozhala”, " $O y$, krasivy nad Volgoy zakaty", and "Dobryy vecher, devushki". The authors of these songs are known, although these songs are called folk songs because they became popular and widely used in ceremonies of seeing off recruits in almost all folk traditions in Russia.

The 'archaic' songs are interesting in that that they have very strict melodic structures. As far as the songs are performed by several people, it is very common in the Udmurt tradition that there will be at least three voices: the main voice performs the lower melodic variations, the supporting voice performs higher melodic variations, and the head register which performs the main voice variations an octave higher. This practice can be associated with Russian polyphonic singing and Turkic head voice singing. Small variations in every voice are allowed.

Usually, the variations are in the range of thirds when it comes to polyphonic singing, and it is also very common that a quarter note can be divided into two eighth notes. The melodic structure in both lines is the same and consists of the same major pentatonic scale sounds (except the last bar where the G is added):

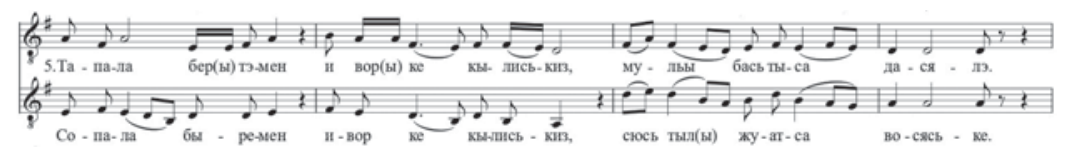

Figure 9. The Tune of Seeing off a Recruit 
There is no meter designation because folk songs 'prefer freedom' in the duration. The notes designate approximate duration relative to each other. The rests were marked according to the singer's pauses in performance, not to make the notation metrically correct.

The rhyme and the meter are less important in rite songs, but there is a visible rhyme between some stanzas, a rhyme that is not constant and visible only in some stanzas. Furthermore, the stanzas may be sung in a variable order. In this case, probably, it would be better to call them not stanzas but couplets. But to call them couplets, we would need refrains between them that we do not have, so it follows that we cannot call them couplets either.

The songs depend on their musical structure and musical accents more. In Udmurt, stress is fixed on the last syllable of a word (it can be different but only with some grammatical forms). If we read the lyrics without their musical accents, they do not sound like poems because the number of syllables, the stress in the words and rhyme do not function the same way as in poems. The stanzas will sound like ordinary sentences in narration, and after you sing them once, it becomes difficult to get rid of musical accents when reading them without the melody again. Therefore, normal word stresses can change due to musical accents.

Here is an example of musical accents that do not match the last-syllable stress of the words bas'tizy, kosizy, shukkem, chuk'yosme, voz'ele:

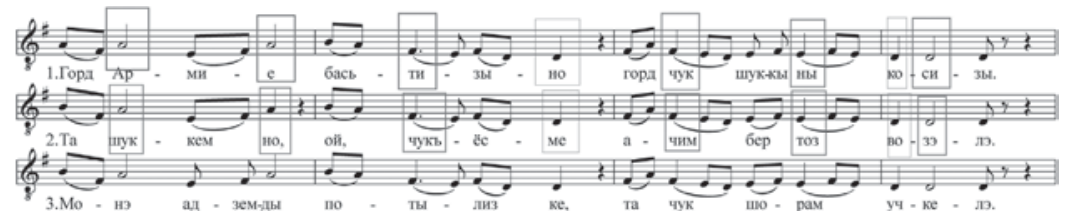

Figure 10. The Tune of Seeing off a Recruit

Although the first notes are on the strong beat, the singer's accents are to be made on the long notes, which are supposed to be on the weak beats. So, this is one more peculiarity in folk songs. 
The grief of recruitment and forced separation from the family are the main motifs of Udmurt recruit songs. In the musicological work of the researcher Rimma Churakova "The Udmurt Wedding Songs", we find important conclusions for us: a peculiar feature of the wedding is that during a conspiracy or at the time of the bride's farewell to the parental house, the songs of 'seeing off a bride' sound. Besides them, any song about a passing youth, about separation, and others can be performed (Churakova 1986: 16). Based on the diapason of melodies, the researcher assumes that the bride's songs "entered the wedding ritual with a later layering" (Churakova 1986: 26). Rimma Churakova, after Petr Pozdeyev, also notes the mutual transitions in the texts of the 'seeing off' rites: "similar plots can be heard in recruiting, guest, and non-ritual lyric songs" (Pchelovodova 2006: 14).

Tatiana Perevozchikova identifies several types of bride lamentation, including: "lamentation songs (characteristic of the southern Udmurt song tradition) with a strong lyrical beginning, which later turned into the category of lyric songs and could be performed outside of any rite; and non-ritual lyrical songs dedicated to the 'seeing off the bride' stage of the wedding" (Perevozchikova 1986: 23). Since 'seeing off the bride' songs also entered the tradition of 'seeing off a recruit', the tendency to perceive lyrical songs as rite songs, which were originally not dedicated to the rite, is clear. Furthermore, it is possible that lamentations were recitative and only later became melodically related to both rites.

The Hungarian researcher Vikár László (1989) has recorded many songs from the Udmurts (Votyaks) who live on the periphery of the ethnic group. He considers these songs archaic since they are based on only three notes. They are different from the songs of the neighboring peoples, and Vikár believes that this suggests that the trichord is primordial and most archaic for the Udmurt. It is this song layer, as the Hungarian scientist noted, that is the basis of the Udmurt song tradition. In our case, this may indicate 
that before triordic singing there could be recitative lamentation in rites that does not imply a developed melodic system. However, in the tradition of the southern Udmurt, including the village of Chutozhmon, there is significant Turkic influence meaning that the tunes are based on major pentatonic scales with singers showing fine ornamental technique.

\section{Symbolism in One Seeing off a Recruit Song}

As we said before, the lyrics of the Seeing off a Recruit tune were polyfunctional for all other rites and festivities, so songs asking for permission to enter, with people giving their purpose for coming and thanking the host for hospitality, could theoretically also be used in the seeing off the bride part of the wedding. However, the lyrics of that talk about hammering a red ribbon onto the beam are used only for Seeing off a Recruit.

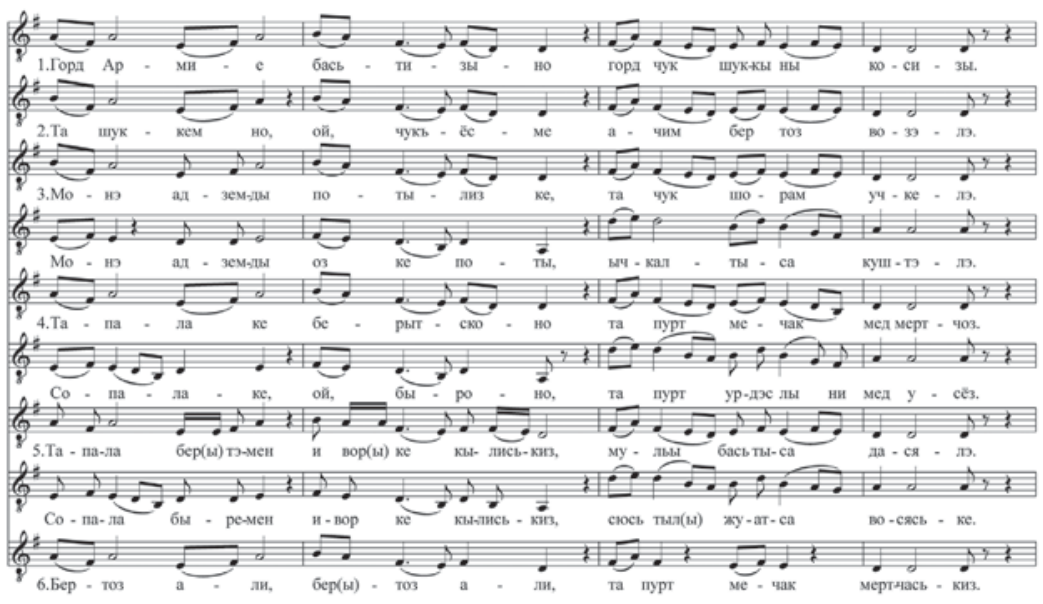

Figure 11. Chuk shukkon gur ('The Song for Hammering a Ribbon'). ${ }^{12}$ 
Chuk shukkon gur

Gord armiye bas'tizy no gord chuk shukkyny kosizy.

Ta shukkem no, oy, chuk"yosme achim bertoz' voz'ele.

Mone addzh'emdy potyliz ke, ta chuk shoram uchkele.

Mone addzh'emdy öz ke poty, yshkaltysa kushtele.

Tapala ke berytskono, ta purt metshak med merchchoz.

Sopala ke, oy, byrono, ta purt urdesly n’i met us'oz.

Bertoz al'i, ta purt metshak merchchas'kiz.

Tapala bertemen ivor kylis'kiz ke, mul'y bas'tysa das'ale.

Sopala byremen ivor kylis'kiz ke, s'us'tyl dzhuatsa vös'as'ke.
The Song for Hammering

a Ribbon

I was taken to the Red Army and they asked me to hammer a red ribbon.

Keep these hammered ribbons until my return.

If you should want to see me, look at my ribbon.

If you do not want to see me, pull it off and throw it away. If I am to come back here, let this knife stick into the floor. If I am to die there, let this knife just fall sideways. He will come back, he will come back, this knife stuck into the floor.

If you will hear the news about my return, buy sunflower seeds.

If you will hear the news about my death, light a candle and pray.

The ribbon is an invariable attribute of the rite of sending a recruit to the army. Often recruits hammered a red flap of material, shreds of multi-colored fabric or red ribbons to the beam with a coin, and later banknotes, too. Money plays the role of tribute to the beam, one of the most sacred parts of the house. Judging by the 
information in sources from the $19^{\text {th }}$ century, a more archaic version of the talisman was the recruit's ring (Bogaevskiy 1888: 49).

Furthermore, I must mention again that this song is performed on an 'archaic' original Seeing off a Recruit tune and can be read as a description of the whole rite: it contains in its lyrics an image of the whole rite from beginning to end and is a kind of commentary on the actions. The structure of the text is composed of the stable motifs of receiving the call-up, certification of suitability for service, parting with a native home and relatives, and a contrast between peaceful everyday life and the soldier's lot.

There has been a modification in the lyrics that might come from the need to adapt to a particular period, for example 'Gord armiya', the Red Army, which was formed only in 1918. However, the rest of the lyrics leave absolutely no doubt that the song is much older than the Red Army because of some significant things mentioned in the song.

In the main recruit tune, the quintessence is the motif of hammering the red ribbon onto the beam. The red ribbon is a symbolic replacement of a young man during his absence. Moreover, it can be considered an icon. Therefore, close attention is paid to the attributes used during the ritual of hammering the ribbon. We have already mentioned that after the recruit has hammered the ribbon to the beam, he has to throw a knife or a hammer in front of himself or over his shoulders, and he must be lucky to throw it so that it does not fall sideways. The knife must stick into the floor or the hammer 'stand on its head'. The recruit throws the knife to the words:

Tapala bertemen ivor kylis'kiz ke, mul'y bas'tysa das'ale.

If I am to come here back, let this knife stick into the floor.

Sopala byremen ivor kylis'kiz ke, s'us'tyl dzhuatsa vös'as'ke.

If I am to die there, let this knife just fall sideways. 
In addition to hammering the red ribbon to the beam in his family house, the recruit will do the same thing at the houses of relatives and villagers, whom he visits with his friends. According to belief, the more ribbons a recruit hammers onto house beams, the more successful his military service will be. In the modern tradition, the ribbon is regarded as a kind of memorial gift to the family home and relatives (s'inpel'/s'inpel'et), the apotropic function of which is directly related to the beam and its protective properties: the ribbon is a gift for the beam, the beam protects the one who hammered in the ribbon (Vladykina et al. 2018: 144-147).

The symbolic function of the red ribbon (gord chuk) is deciphered in the tradition as the ribbon becoming the symbolic material substitution of the soul of the recruit who is leaving for the army: " $T a$ shukkem no, oy, chuk'yosme achim bertoz'voz'ele" ('Keep these hammered, oh, my ribbons until my return'). Tatiana Vladykina et al. (2018) give an example of part of a Seeing off a Recruit song that is likely to be a continuation of lyrics of the song from Chutozhmon:

Etot vbityy, oy, moy chuk

khran'it'e do moyego

vozurashchen'iya,

Esl'i vernus', oy, sam zubami vyrvu, esl'i sam vernus', zubami vyrvu.

Esl'i pyl', oy, s'ad'et, smetayt'e, oy, krylyshkom.

Esl'i pyl', oy, s'ad'et, smetayt'e, oy, krylyshkom.

Esl'i men'a n'e zakhot'it'e uvid'et', vyrvit'e i bros't'e,
Keep this ribbon, oh, my

ribbon until my return,

If I return, oh, I will pull it out with my teeth, if I return, I will pull it out with my teeth.

If the dust, oh, sits down (on the ribbon), sweep it off, oh, with a wing,

If the dust, oh, sits down (on the ribbon), sweep it off, oh, with a wing,

If you want to see me, pull out and throw (the ribbon), 
Vyrvit'e i bros't'e da v reku Volgu.

Esl'i v Volgu-reku brosit'e, pust'ko mn'e on priplyv'ot, Esl'i v Volgu-reku brosit'e, pust' ko mn'e on priplyv'ot.
Pull out and throw (the ribbon) into the Volga River. If you throw it into the Volga River, let it sail to me, If you throw it into the Volga River, let it sail to me.

The mood for return is revealed in the song itself since the recruit promises to pull out the ribbons upon his return, which he must do in every house with his teeth. According to informants, this is to show that an adult, a strong man, had returned instead of young inexperienced boy. In this way the recruit also shows his respect for the villagers, although this action is not connected with any part of the rite.

Here is one more interesting thing to pay attention to in the next lines:

Tapala bertemen ivor kylis'kiz ke, mul'y bas'tysa das'ale.

If you will hear the news about my return, buy sunflower seeds.

Sopala byremen ivor kylis'kiz ke, s'us'tyl dzhuatsa vös'as'ke.

If you will hear the news about my death, light a candle and pray.

Informants explain that sunflower seeds ( $\left.m u l^{\prime} y\right)$ are a favorite for recruits as they cannot find them in the army. However, the semantics of this word is not entirely clear even to old-timers. Looking deeper into semantics in the Slavic Antiquities ethnolinguistic dictionary there is the following explanation: "seed, seeds - a symbol of future life, fertility and abundance. S. unites the beginning and end of life: the 'dead' S. thrown into the earth turn into a new plant, tree, grass, bread, etc.” (Ethnolinguistic Dictionary: 616). Thus, 
the image of the seed here was not random because its meaning is endowed with a mythological idea of a new life and fertility. We can conclude that upon return the soldiers form a kind of family, on the one hand, and attain the status of a man, on the other.

Regarding the beam, there is no wonder the Udmurts preferred to build houses of spruce or pine. These trees with long, even trunks fit well in the log house, joining tightly together with the large number of resins contained in them preventing rapid decay. Such houses also retained heat well. The ribbon hammered into the beam is semantically adequate to identify a recruit with a tree. In some villages, recruits hammered a shred or ribbon and a coin into a birch, pine, or spruce in the sacred places of the village, which could symbolise both the gift to the tree and the person's involvement in his native world (the same definition as that of the gift to the beam). The pine tree symbolises a young man, and that tree, into which the recruit hammers the ribbon, is considered to guard the soldier when he goes to a 'foreign' land. A tree becomes a substitute for the soul of the recruit who has left home; this option, apparently, is more archaic than the action with the beam.

"During the 'seeing off' rite, the recruit, climbing up the spruce, cut down several of the upper branches, exposing the trunk. The upper branches remained, giving the tree a human appearance, which corresponds to its name later [see below]. Sometimes the top of the tree was directly cut down, but this had to be done so that it continued to grow. It was believed that if the tree after that dries up, then this person will not return home, if it does not dry up, he will return from service" (Vladykina et al. 2018: 144-147).

These trees then receive special names, for example yyro kyzspruce with head, chyrtyo kyz - spruce with neck, or kartuzo kyzspruce with a hat. 
The fact that the recruit throws a knife to the floor could also be connected with the three-part vision of the world: the higher - the world of God, the middle - the world of humans, the lower - the world of evil. It can be assumed that the beam is part of the higher world, and the floor is the lower world. The recruit throws the knife to know if he will die or not, i.e. if the lower world wants to take him or not. The knife, in turn, has the meaning of male principle and protection. Since it was a male instrument and was close to the recruit from childhood, it was also a symbol of the recruit.

\section{Conclusion}

The main purpose of this article was to initiate research about musical aspects of Seeing off a Recruit on the basis of the material collected in the village of Chutozhmon.

I started by presenting a detailed desciption of the ritual including, or mentioning, the songs that mark the structure of the ritual. The roles and motifs of most of songs are quite clear, while the song about hammering the red ribbon onto the beam are dealt with separately at the end of the article. The ritual contains a certain set of motifs that illustrate emotional expression and state of mind. Having received the call-up, the recruit does not resist his fate, but obeys it: leaving for the army is perceived by him as the norm. The same attitude applies to the micro-plot with the knife. According to researchers, submission to one's fate "is not connected in any way with ethnic weakness or silence, but is determined at the level of worldview within which any life situation was perceived as predestination from above, therefore the question of confrontation was impossible in principle" (Pchelovodova 2009).

As Elena Boykova and Tatiana Vladykina concluded, according to ethnographic data the earliest form of the rite consisted of two main stages: moving from house to house, and departure (Boykova, Vladykina 1992: 15). The two-part nature of the ritual has been 
preserved in the same ritual among the Besserman. While some ritual episodes have been lost, the key actions are:

1. A home feast on the eve of departure to the army, preserving the initial ritual episode of tying a belt and towels;

2. The action, performed on the day of departure, containing the central climax episode of the rite of 'leaving the house' (Shakhovskoy 1993: 5).

The available material makes it possible to give the rite a more detailed structure:

a) reception of conscription papers from the military by a young man;

b) sharing the news with the neighborhood and starting to prepare for the rite;

c) the rite activities: moving from house to house, hammering a red ribbon in every house, tying ribbons, a belt and towels to the recruit, etc.;

d) farewell meeting at the house of the recruit's family;

e) seeing off the recruit to the army.

The Udmurt songs of both 'archaic' and 'old' layers have the function of commentary on the rite, telling of things that happen in the rite and conveying the feelings and emotions of the recruit and his family. This fact makes the process of reconstruction more logical and easier to understand.

Table 1. Functions of the Songs of the Rite of Seeing off a Recruit (songs from the village of Chutozhmon).

\begin{tabular}{|l|l|}
\hline \multicolumn{2}{|c|}{ The 'archaic' layer } \\
\hline \multicolumn{1}{|c|}{ Song } & \multicolumn{1}{|c|}{ Function } \\
\hline “Us'toz(y) meda, uz(y) meda (y) & asking for permission to enter \\
uk ta tshogam $(y)$ no ös"yosse" & the house \\
\hline $\begin{array}{l}\text { "Dzh'ech ivor no kylis'kiz no, } \\
\text { mi pyrono karis'kim" }\end{array}$ & $\begin{array}{l}\text { explanation of the purpose } \\
\text { of the visit }\end{array}$ \\
\hline
\end{tabular}




\begin{tabular}{|c|c|}
\hline $\begin{array}{l}\text { "Taule no, taule no, s'udem }(y) l y \\
\text { no s'ektam }(y) l y "\end{array}$ & $\begin{array}{l}\text { thank for hospitality and good } \\
\text { wishes for the hosts }\end{array}$ \\
\hline $\begin{array}{l}\text { "Gord Armiye bas'tizy no gord } \\
\text { chuk shukkyny kosizy" }\end{array}$ & $\begin{array}{l}\text { hammering the ribbon; expla- } \\
\text { nation of the situation of the } \\
\text { rite and explanation of actions } \\
\text { the recruit performs }\end{array}$ \\
\hline $\begin{array}{l}\text { "E, kyl'oz uk, kyl'oz ik uk ta } \\
\text { Chutozhmon kalyked” }\end{array}$ & $\begin{array}{l}\text { farewell to the village and all } \\
\text { people }\end{array}$ \\
\hline $\begin{array}{l}\text { "Uboyen-uboyen }(y) \text { vozh } \\
\text { sugone, vozh sugon }(y) \text { shashy } \\
\text { kad'(y) mygory" }\end{array}$ & $\begin{array}{l}\text { expression of recruit's feelings } \\
\text { and experiences }\end{array}$ \\
\hline \multicolumn{2}{|c|}{ The 'old' layer } \\
\hline "Chastushkaos" & $\begin{array}{l}\text { dance tune and song; atten- } \\
\text { tion to talents of the recruit }\end{array}$ \\
\hline $\begin{array}{l}\text { "Iz no, mu no pil'is'ke no- } \\
\text { ad'amily chidano" }\end{array}$ & $\begin{array}{l}\text { narration about the hard life } \\
\text { of ordinary people and about } \\
\text { the future of youth }\end{array}$ \\
\hline $\begin{array}{l}\text { "Korkas'tym }(y) \text { potykum, } \\
\text { neniyenym l'ukis'kykum" }\end{array}$ & $\begin{array}{l}\text { the narration about the re- } \\
\text { cruit's leaving home and his } \\
\text { desires }\end{array}$ \\
\hline $\begin{array}{l}\text { "Kytky, d'ad'i, par val"yoste, } \\
\text { us'ty, memi, kapkade" }\end{array}$ & $\begin{array}{l}\text { narration about people whom } \\
\text { the recruit leaves; thinking } \\
\text { about the meaning of life }\end{array}$ \\
\hline $\begin{array}{l}\text { "Serego no serego ta } \\
\text { Chutozhmon busyyed }(y) "\end{array}$ & $\begin{array}{l}\text { narration about the village } \\
\text { and people the recruit leaves }\end{array}$ \\
\hline \multicolumn{2}{|c|}{ The 'modern' layer } \\
\hline $\begin{array}{l}\text { "Kak rodnaya men'a mat' } \\
\text { provozhala" }\end{array}$ & $\begin{array}{l}\text { entertaining song about the } \\
\text { day of farewell }\end{array}$ \\
\hline $\begin{array}{l}\text { "Dobryy vecher }(y), \text { devushki, } \\
\text { dobryy vecher }(y), \text { milyye" }\end{array}$ & $\begin{array}{l}\text { dialogue of recruits with girls } \\
\text { about the soldiery's honour }\end{array}$ \\
\hline $\begin{array}{l}\text { "Oy, krasivy nad Volgoy } \\
\text { zakaty” }\end{array}$ & $\begin{array}{l}\text { dialogue with beloved and } \\
\text { true love }\end{array}$ \\
\hline
\end{tabular}


The division of these songs into three layers of 'archaic', 'old', and 'modern' helped analyse the functions of the songs in the rite and how they could be brought to the rite. There are six songs in the 'archaic' category, five of which are sung to the same tune and one to another recruit rite tune that could be brought from another village tradition. Among the 'old' songs there are four Udmurt songs as well as an example of the ditties that can be sung to different melodies. And as for the 'modern' layer, there are three Russian songs from the Soviet period.

The modern world surrounding us and its conditions have a strong influence on people, regardless of where they live - in village or city. Nevertheless, even in a small village, knowledge and experience transmitted by the ancestors still exists. Expedition materials recorded expand our knowledge of the existence of the traditions, which allows us to introduce them in the context of world culture.

The material studied can make it possible to recreate a complete picture of the rite and to conduct it for future recruits.
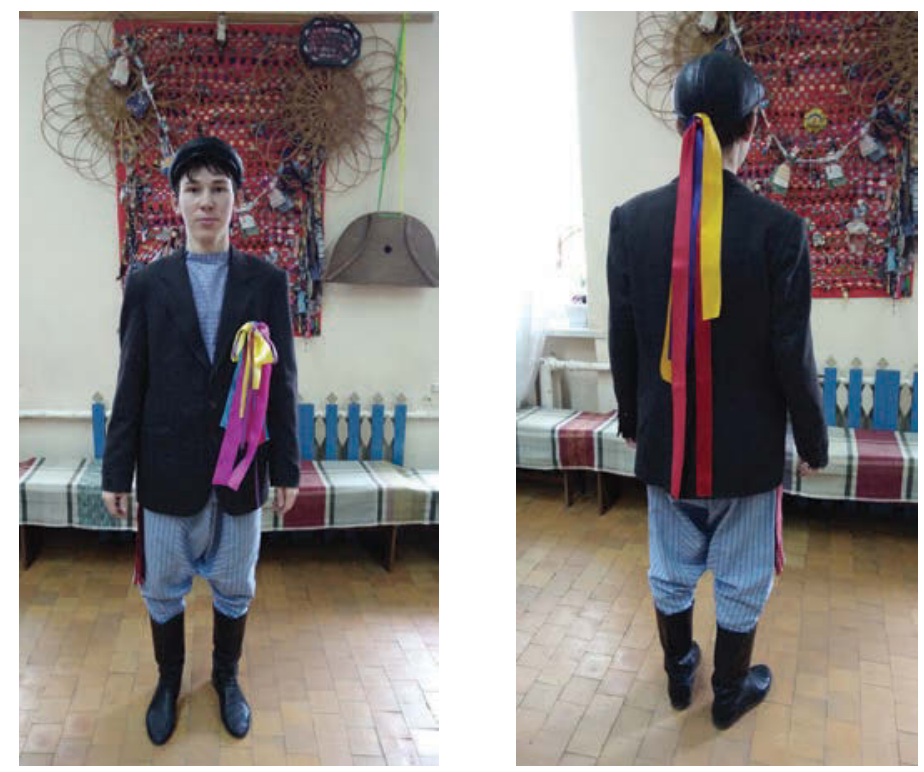

Photos 1 \& 2. Recruit. Izhevsk, 2019. Photos by Margarita Khamatova. 


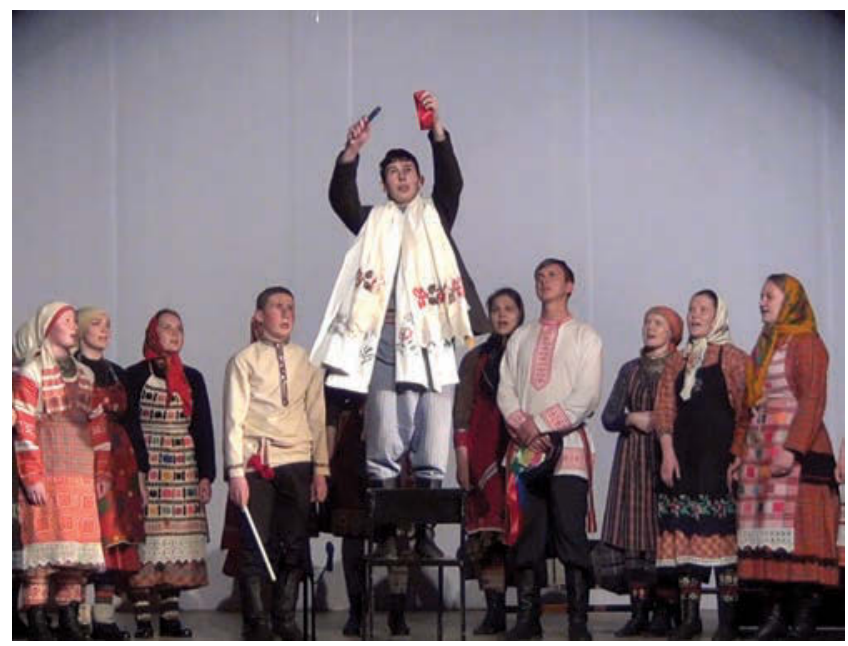

Photo 3. Seeing off a Recruit ritual Mise-en-scène by the students of the Republican Musical colledge, Izhevsk.

Source: https://youtu.be/KBtPX7joR1c.

\section{Notes}

1 Udmurt Institute of History, Language and Literature of the Ural Branch of the Russian Academy of Sciences.

2 FWM 2015. Recorded from Lyubov' Andreevna Lebedeva, born 1941, in Chuzhtomon, by Valeriia Fedorova, in Baykuzino.

3 FWM 2018. Recorded from Lyubov' Andreevna Lebedeva, born 1941, in Chuzhtomon, by Valeriia Fedorova, in Baykuzino.

4 FWM 2015. Recorded from Lyubov' Andreevna Lebedeva, born 1941, in Chuzhtomon, by Valeriia Fedorova, in Baykuzino.

5 FWM 2018. Recorded from Lyubov' Andreevna Lebedeva, born 1941, in Chuzhtomon, by Valeriia Fedorova, in Baykuzino.

6 FWM 2018. Recorded from Lyubov' Andreevna Lebedeva, born 1941, in Chuzhtomon, by Valeriia Fedorova, in Baykuzino.

7 The Russian songs within this ritual are performed by Udmurts. We have chosen to adopt Udmurt transliteration principles, taking into account the phonetic peculiarities of Udmurt pronounciation. (Editors) 


\section{Valeriia Fedorova}

8 FWM 2008. Recorded from Nina Ivanovna Petrova, born 1934, in Chuzhtomon, by Irina Pchelovodova, in Baykuzino.

9 FWM 2015. Recorded from Nina Ivanovna Petrova, born 1934, in Chuzhtomon, by Valeriia Fedorova, in Baykuzino.

${ }^{10}$ FWM 2015. Recorded from Lyubov' Andreevna Lebedeva, born 1941, in Chuzhtomon, by Valeriia Fedorova, in Baykuzino.

${ }^{11}$ FWM 2015. Recorded from Lyubov' Andreevna Lebedeva, born 1941, in Chuzhtomon, by Valeriia Fedorova, in Baykuzino.

${ }^{12}$ FWM 2015. Recorded from Lyubov' Andreevna Lebedeva, born 1941, in Chuzhtomon, by Valeriia Fedorova, in Baykuzino.

\section{List of the informants}

The songs and detailed description of the rite of Seeing off a Recruit were recorded in expeditionary semi-structured interviews in the villages of Chutozhmon and Baikuzino, and the city of Izhevsk (the places of residence of interviewees at the time of the interviews in the years 2015-2018) from the following informants (tradition bearers):

Bykova, Galina Stepanovna, born in 1942 in Chutozhmon;

Fedorova, Alevtina Petrovna, born in 1969 in Chutozhmon;

Fedorova, Petr Nikandrovich, born in 1935 in Chutozhmon;

Lebedeva, Lyubov' Andreevna, born in 1941 in Chutozhmon;

Petrova, Nina Ivanovna, born in 1934 in Chutozhmon.

\section{References}

Atamanov, M. 2005. Ot Dondykara do Ursygurta. Iz istorii udmurtskikh regionov. Monografiya [From Dondykar to Ursygurt. From the History of Udmurt Regions]. Izhevsk: Udmurtia.

Bogaevskiy, P. 1888. Ocherki byta Sarapul'skikh votyakov [Essays about the Everyday Life of the Sarapul Votyak]. Sbornik materialov po etnografii pri Dashkovskom muzee [Collection of Materials about Ethnography at the Dashkovski Museum]. Vol. 3. Moscow: [b.i.].

Boykova, E., Vladykina,T.1992.Udmurtskiy fol'klor.Pesniyuzhnykh udmurtov: Materialy i issledovaniya [Udmurt Folklore. Songs of the Southern Udmurt: 
Materials and Research]. Vol. 1. Izhevsk: Udmurtskiy institut istorii, yazyka i literatury Uralskogo otdeleniya Rossiyskoy akademii nauk.

Cerban, M. 2017. Types of Relation Between Subordinated Clauses in Wake for Susan by Coman Mccarthy. Iulian Boldea (ed.) Literature, Discourses and the Power of Multicultural Dialogue. Tîrgu Mureș : Arhipelag XXI Press, pp. 89-94.

Gazieva, T. 2014. Pesennyy fol'klor udmurtov [The Singing Folklore of the Udmurt]. https://schoolfiles.net/1056715 (accessed 12.05.2021).

Halliday, M. A. K., Hasan, R. 1976. Coherence in English. London: Longman.

Hasan, R. 1984. Coherence and Cohesive Harmony. In: Flood, J. (ed.) Understanding Reading Comprehension. Delaware: International Reading Association, pp. 181-219.

Hatten, R. n.a. Embodying Sound: The Role of Semiotics. Lecture 2. https:// semioticon.com/sio/courses/musical-gesture/role-of-semiotics/.

Khristolyubova, L. 1984. Semeynyye obryady udmurtov (traditsii i protsessy obnovleniya) [The Family Rituals of the Udmurt (Transition and Innovation Processes)]. Izhevsk: Udmurtia.

Lázár, K. 2006. Finnugor nyelvü népek zenéje [The Music of the FinnoUgric Peoples]. Budapest.

Mahlberg, M. 2006. Lexical Cohesion. Corpus Linguistic Theory and Its Application in English Language Teaching. International Journal of Corpus Linguistics 11 (3), pp. 363-383.

Morris, J., Hirst, G. 1991. Lexical Cohesion Computed by Thesaural Relations as an Indicator of the Structure of Text. Computational Linguistics. Vol. 17, No. 1.

Pchelovodova, I. 2006. Udmurtskiye liricheskiye pesni: istoki i formirovaniye traditsii [The Udmurt Lyrical Songs: The Sources and the Formation of Tradition]. Rukopis' dissertatsii na soiskanie uchenoy stepeni kandidata filologicheskikh nauk. PhD Dissertation. Manuscript, 10.01.2009. Izhevsk.

Pchelovodova, I. 2009. Osobennosti kompozitsii udmurtskikh liricheskikh pesen [Peculiarities of the Composition of the Udmurt Lyrical Songs]. Vestnik Vyatskogo gosudarstvennogo gumanitarnogo universiteta [Messenger of the Vyatka State University in Humanities] 1, pp. 108-114.

Perevozchikova, T. 1986. Svoyeobraziye zhanra prichitaniy v udmurtskom fol'klore [Peculiarities of the Lament Genre in the Udmurt Folklore]. 
Problemy tvorcheskikh svyazey udmurtskoy literatury i fol'klora [Problems of the Creative Connections between Udmurt Literature and Folklore]. Izhevsk: Nauchno-issledovatel'skiy institut pri Sovete Ministrov Udmurtskoy ASSR, pp. 18-49.

Shakhovskoy, A. 1993. Pesni besermyanskogo obryada provodov v armiyu: Uchebnoye posobiye [Songs of the Besserman Ritual "Seeing of a Recruit"]. Moscow: Rossiyskiy institut iskusstvoznaniya.

Tolstoy, N. 2004. Slavyanskiye drevnosti: Etnolinguisticheskiy slovar' [Slavic Antiquities: Ethnolinguistic Dictionary]. N. Tolstoy (Editor-inchief). Vol. 3. Moscow: Mezhdunarodnyye otnosheniya.

Tolstoy, N. 2009. Slavyanskie drevnosti: Etnolinguisticheskiy slovar' [Slavic Antiquities: Ethnolinguistic dictionary]. N. Tolstoy (editor-in-chief). Vol. 4. Moscow: Mezhdunarodnye otnosheniya.

Vershinina, E., Vladykina, T. 2014. Udmurtskiy fol'klor. Pesni yuzhnykh udmurtov [Udmurt Folklore. Songs of the Southern Udmurt]. Vol. 3. Izhevsk: Udmurtskiy institut istorii, yazyka i literatury Uralskogo otdeleniya Rossiyskoy akademii nauk.

Vladykina, T., Glukhova, G., Panina, T. 2018. Chuk v traditsionnoy kul'ture udmurtov [The Ribbon "Chuk" in the Traditional Culture of the Udmurt]. Traditsionnaya kul'tura. Vol. 19 (1), pp. 139-151.

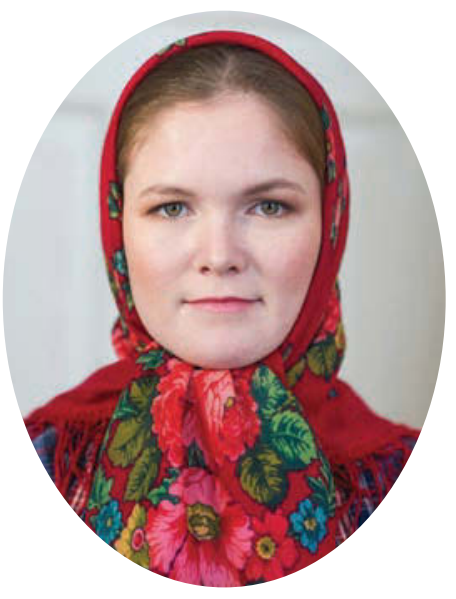

Valeriia Fedorova is a doctoral student at the Multilingualism Doctoral School, University of Pannonia (Veszprém, Hungary), and doctoral student of Music Sciences at the Ankara Music and Fine Arts University (Ankara, Turkey). Her main interest in research is Udmurt folk tradition from the sociolinguistic and semiotic point of view.

e-mail: loptem.gon@ya.ru 